\title{
The Pleistocene drainage pattern in the Lower Rhine Basin
}

\author{
W. Boenigk \\ Geologisches Institut, Abt. Quartärgeologie, Universität zu Köln, Zülpicher Strasse 49a, \\ 50674 Köln, Germany; e-mail: boenigk@uni-koeln.de
}

Manuscript received: August 2000; accepted: January 2002

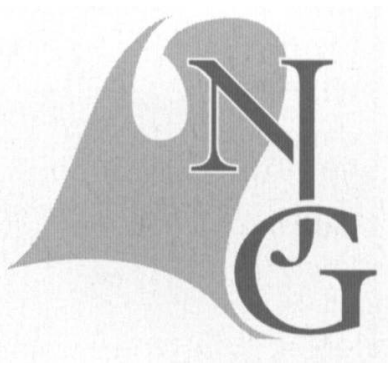

\begin{abstract}
During the Pleistocene the drainage pattern in the Lower Rhine Basin changed twice, from a flooding of the whole basin by the river Rhine from SW to NE to an influence restricted to the NE only.

The first dominance of the river Rhine is documented from the Reuverian to the Tiglian, the second one in the Cromerian. In between this time, the Meuse River drained the central Lower Rhine Basin in NE direction. For the sediments of that river, the term 'Holzweiler Formation' is introduced. Since the Late Cromerian, the influence of the Rhine is again restricted to the NE of the Lower Rhine Basin. The central part of the basin is drained by small local rivers.
\end{abstract}

Key words: Drainage, heavy minerals, lithostratigraphy, Lower Rhine Basin, Pleistocene

\section{Introduction}

The Rhine River drains the Lower Rhine Basin along the eastern part of the uplifted Köln Block more or less parallel to the main tectonic faults (Fig. 1). The Meuse River drains this basin only in the NW and flows perpendicularly to the main faults.

Sedimentological features as well as petrographic compositions of the sediments were used to reconstruct the evolution of the Quaternary drainage pattern in the Lower Rhine Basin. Some new outcrops in the SW - open cast mine Inden - and in the NE open cast mine Garzweiler - allow to reconstruct the drainage pattern more detailed than previously done by Breddin (1955), Schnütgen (1974), Boenigk (1978a, b) and Prüfert (1994).

\section{Observation}

Pebble countings and heavy mineral analyses are excellent stratigraphic tools in Pleistocene sediments of the Lower Rhine Basin. Four different pebble assemblages can be determined (Fig. 2):

1. Tertiary gravel with its source area in the Rhenish Massif (Rh-M) only: This assemblage is characterised by more than $90 \%$ of quartz pebbles in the coarse pebble fraction. The residual consists of quartzites only.

2. Tertiary gravel from an extended source area further to the south: the Kieseloolite (KOO) gravel. Typically, the quartz content ranges from 80 to $90 \%$. Additionally there occur some minor content of quartzite and other siliceous pebbles. The source areas of KOO pebbles are the Jurassic rocks in eastern France indicating Tertiary fluvial activity of the pre-Rhine system.

3. Pleistocene Rhine gravel (Rhine): The composition of this gravel is characterised by a remarkable decrease in quartz content compared with the above mentioned Tertiary gravel assemblages. The percentage of quartz decreases from about $65 \%$ to less than $20 \%$ from the bottom to the top. The 

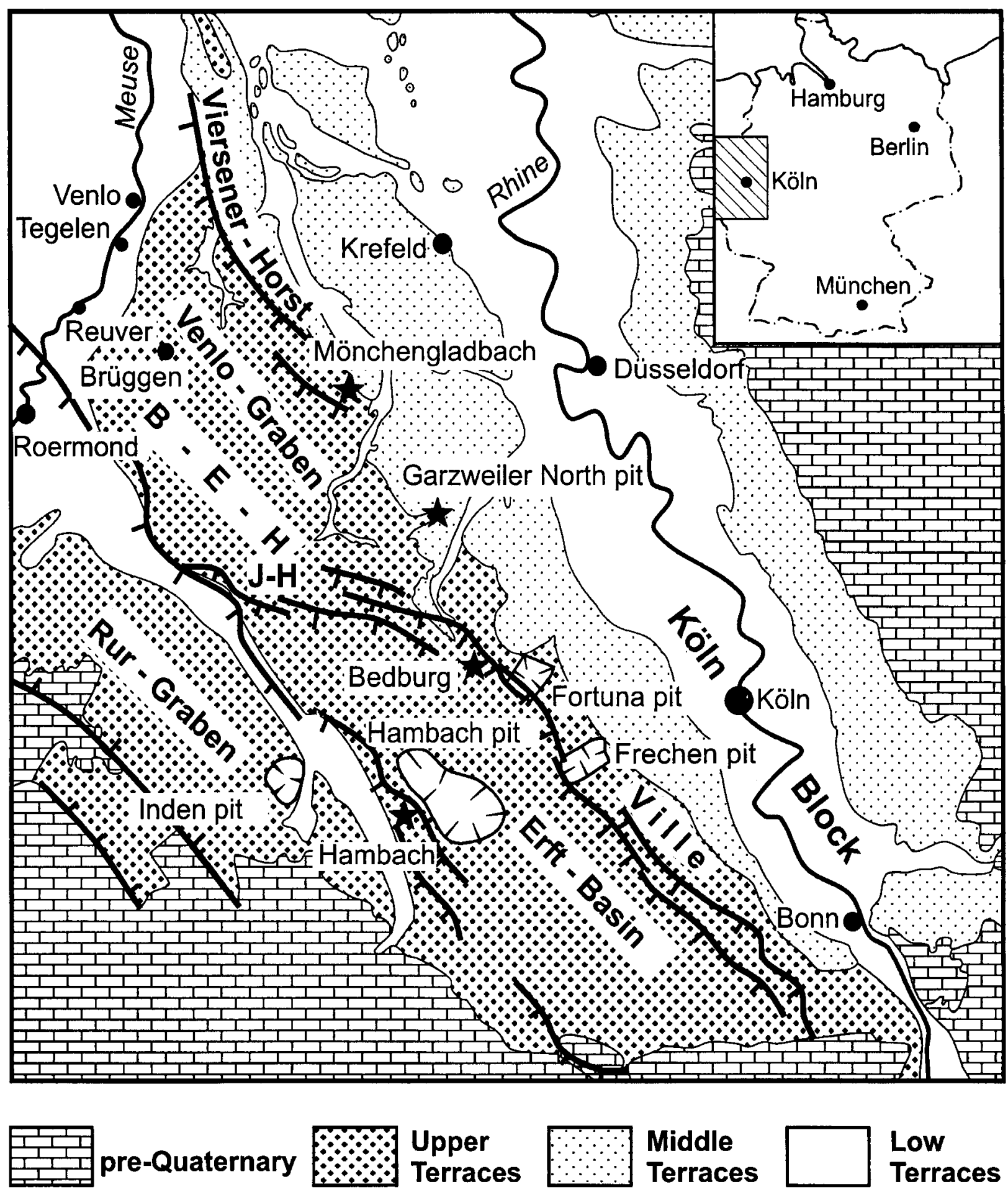

Fig. 1. Lower Rhine Basin with Pleistocene terraces and Holocene drainage pattern of the Rhine and Meuse rivers. J-H $=\mathrm{Jackrather} \mathrm{Horst,}$ B-E-H = Brüggen-Erkelenzer Horst.

presence of radiolarites in the pebble spectra gives evidence of the Alps as source area.

Volcanic components are typical for Middle Pleistocene deposits, indicating volcanic activity in the Eifel area during the past 700.000 years.

4. Meuse gravel (Meuse) in the central Lower Rhine Basin: Quartzite pebbles predominate in this gravel. The occurrence of up to $20 \%$ of angular flint pebbles from Cretaceous rocks is typical for these deposits and rocks. Additionally, Revin Quartzite - Cambrian in age - can be taken as typical pebble for these deposits.

Six different spectra of heavy minerals can be distinguished in the Lower Rhine Basin (Fig. 2).

1. Material from the Rhenish Massif (Rh-M) pro- 

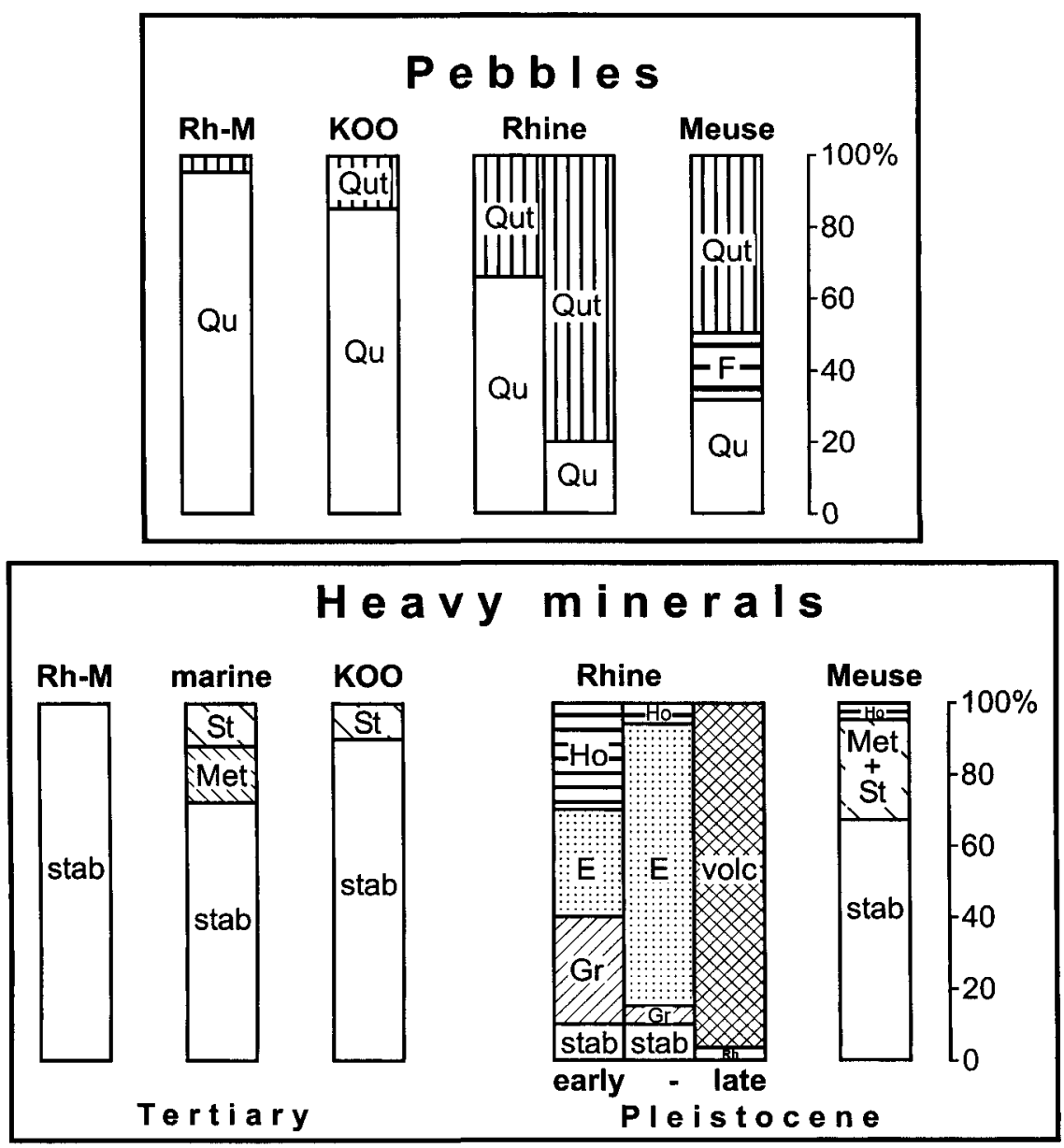

Fig 2. Typical pebble and heavy mineral associations of Tertiary and Quaternary sediments in the Lower Rhine basin. Rh-M = Rhenish Massiv; $\mathrm{KOO}=$ Kieseloolite Formation; $\mathrm{stab}=$ stable; $\mathrm{Met}=$ Kyanite, Sillimanite, Andalusite; $\mathrm{St}=$ Staurolite; Ho $=$ Hornblende; $\mathrm{E}=\mathrm{Epidote}$ group and Alterites; $\mathrm{Gr}=$ Garnet; volc $=$ volcanic; $\mathrm{Qu}=\mathrm{Quartz} ; \mathrm{Qut}=$ Quartzite; F $=$ Flint

vides extremely stable minerals only: zircon, tourmaline and rutile are dominating. When there are rocks and/or sediment from the Buntsandstein formation, the tourmaline content increases.

2. Tertiary marine (marine) sediments are characterised by extremely stable heavy minerals and a high percentage of metamorphic minerals. Staurolite, kyanite, sillimanite and andalusite are abundant. Staurolite and kyanite dominate in this spectrum.

3. Pliocene Kieseloolite (KOO) sediments are characterised by a stable heavy mineral spectrum with high content of staurolite.

4. The Pleistocene sediments of the river Rhine (Rhine) differ completely in their heavy mineral association and in their carbonate, mica and feldspar content from the Tertiary sediments. In the lower part of the Pleistocene sediment record, the most frequent heavy minerals are garnet, epidote and green hornblende. In the middle part of the record, Cromerian in age, epidote dominates in most cases.
5. The younger Rhine sediments, younger than Cromerian, are characterised by volcanic heavy minerals (Rhine) from the East Eifel volcanic field.

6. Meuse sediments (Meuse) from the central part of the Lower Rhine Basin can be characterised by stable heavy minerals. The association is very similar to the mineral content of the Tertiary marine sands (marine) in the Lower Rhine Basin. Staurolite and kyanite are common; sillimanite and andalusite are rather additional. A typical greenbrown-yellowish hornblende ("Vogues Hornblende') occurs, different to the green or brown one of the Eifel area.

In the Lower Rhine Basin, pebble and heavy mineral frequencies allow to subdivide the Pliocene and Pleistocene sediments into five main units, whereas the pebble and heavy mineral spectra with their source exclusively in the Rhenish Massif $(\mathrm{Rh}-\mathrm{M})$ are not included. These sediments are known from the Paleogene only.

The section studied in this article shows the fol- 
lowing subdivisions from the bottom to the top (Tab.1):

1. The Kieseloolite (KOO) Formation (Fliegel \& Stoller, 1913):

These Pliocene sediments with KOO pebble and heavy mineral spectrum are equivalent to the KOO terraces to the Middle Rhine area (Kaiser, 1961).

2. The Tegelen Formation (Zagwijn, 1960):

In the area of the Erft-Block and the Venlo-Graben these sediments consist of Pleistocene Rhine deposits with a quartz pebble content higher than 55 $\%$ and with a heavy mineral spectrum with garnet, epidote and green hornblende. These sediments can be treated as equivalent to parts of the Early Pleistocene terraces in the Middle Rhine area (Hoselmann, 1994).

3. The Holzweiler Formation:

The Tegelen Formation is covered by sediments of the Meuse River. They occur mainly in the central part of the Lower Rhine Basin. The pebble content and the heavy mineral association are very typical as Fig. 2 (Meuse) shows. These sediments are correlated with parts of the Early Pleistocene terraces of the Middle Rhine area and with the Kedichem Formation (Boenigk, 1978b) as described in the Dutch stratigraphy (Zagwiin, 1957; Doppert et al., 1975).

In recent papers (Ebbing et al., 1999; Weerts et al., 2000) the term 'Kedichem Formation' is no longer used. Parts of former Kedichem Formation sediments, consisting of Rhine and Rhine/Meusemix sediments, are now included in the Tegelen
Formation. Meuse sediments occur in the Eijsden Formation, (Tab.1) (Ebbing et al., 1999).

In the central part of the Lower Rhine Basin, Meuse and Rhine/Meuse mixed sediments are quite characteristic and represent a very good key horizon for subdividing the Lower to Middle Pleistocene deposits in this area. Klostermann (1992) does not mention these sediments in the stratigraphic column. With respect to their importance for the understanding of the drainage history in the Lower Rhine Basin they are defined as Holzweiler Formation.

The type area is located in the northern part of the Erft basin, north of a line from Hambach to Bedburg, including the Jackrather Horst and the southern part of the Venlo Graben between the Jackrather Horst and Mönchengladbach (Fig. 1). The Holzweiler Formation consists of Meuse sediments - coarse gravel and sand with clay lenses underlain by Rhine sediments of the Tegelen Formation and overlain by Rhine sediments of the Upper Terrace Sequence i.e. 'HauptterrassenFolge' after Burghardt \& Brunnacker (1974) and Schnütgen (1974).

The following sections may serve as type-sections: Gravel pit Holzweiler: Geological map, sheet 4904 Titz, R 27 375, H 60250 described by: Schnütgen (1974) section Nr. 94, and Boenigk (1978b), section 16 , between $70-76,5 \mathrm{~m} \mathrm{ASL}$ and open cast mine Garzweiler: Geological map, sheet 4905 Grevenbroich, R $35100, \mathrm{H} 62300$ described in Fig. 3, section A III + IV, section B II + III bottom

Table.1. Stratigraphy of the Lower Rhine Basin.

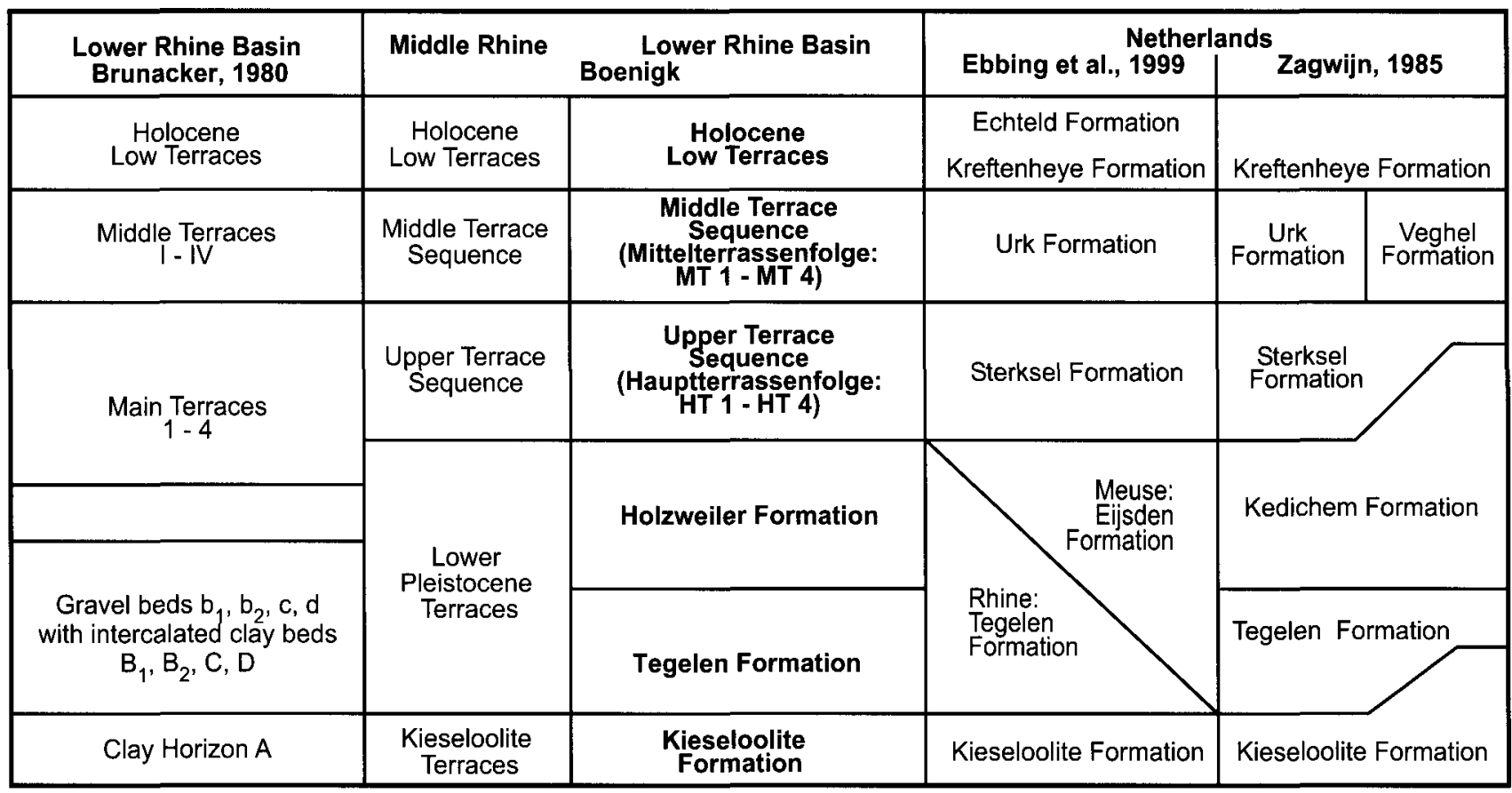




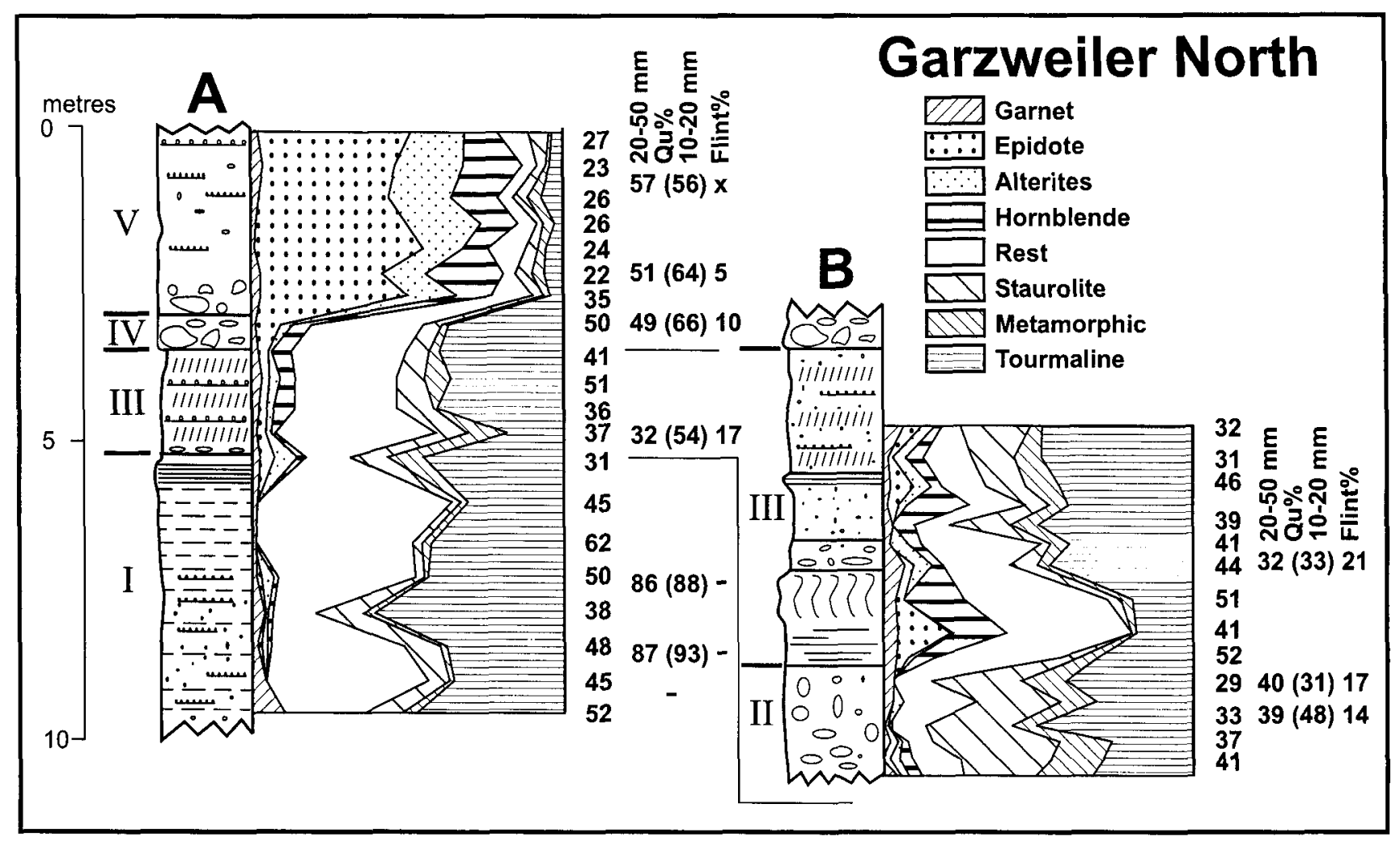

Fig. 3. Heavy mineral and pebble spectra from a section in the brown coal open cast mine Garzweiler North (Fig. 1) with Kieseloolite Formation (I), Holzweiler Formation (II-IV) and Upper Terrace Sequence (V). Profile A: R 35300, H 61560, Profile B: R 35100,H 62300.

at $50 \mathrm{~m} \mathrm{ASL}$ and a maximum thickness of $7 \mathrm{~m}$. A typical section (Fig. 3) for the central part of the Lower Rhine Basin with well-developed Meuse sediments is exposed in the brown coal open cast mine Garzweiler North (Fig. 1). The section starts with gravel and sand topped by a clay horizon designated to represent the Kieseloolite Formation. These deposits are covered by Meuse sediments (Fig. 3, II - IV) starting with coarse gravel of the river Meuse (Fig. 3, II). Boulders of more than 30 $\mathrm{cm}$ in clast size are common. They are covered by sand with humic clay beds (Fig. 3, III) from the Meuse River, evidenced by their heavy mineral content. At the top of the Meuse sediments (Fig. 3 , IV), coarse gravels with flint and Revin boulders up to $30 \mathrm{~cm}$ in diameter are abundant.

In the uppermost part of the profile, the Meuse sediments are reworked and mixed with those of the Rhine River. The fluvial activity of the Rhine shows increased influence in this area. The youngest fluvial sediments of this section, that were solenmly deposited by the Rhine, are correlated with the Upper Terrace Sequence (Fig. 3,V).

Most important is the fact, that in the northeastern part of the Lower Rhine Basin, Meuse gravels are accumulated without any constituents of Rhine sediments. Farther to the NE, sediments of Early Pleistocene age are not exposed, most likely due to the erosion of terrace steps of Middle Pleistocene age.

4. The Upper Terrace Sequence (Brunnacker, 1980): As a result of pebble counts (Schnütgen, 1974; Burghardt \& Brunnacker, 1974) and by heavy mineral analysis (Boenigk, 1978b) the Upper Terrace Sequence was subdivided into four members, HT1 - HT4. The sediments consist of river Rhine sediment with a decreasing quartz pebble content of about $55 \%$ in HT1 down to less than $40 \%$ in HT3 (Schnütgen, 1974; Burghardt \& Brunnacker, 1974). The heavy mineral association is dominated by epidote. A further subdivision is possible by the abundance of green hornblende, alterites (saussurite) and volcanic minerals (Boenigk, 1978b). The type section is described as section 1 in the open cast brown coal mine Frechen in Boenigk, 1978b. The same subdivision can be found in the Sterksel Formation (Zagwijn, 1957) in the Netherlands where Zonneveld, 1947 distinguished several heavy mineral zones. The similarity is so obvious that the correlation HT1 = Sterksel zone, HT2 = Weert zone and HT3 = Rosmalen zone is striking. (Boenigk, 1978b). The Upper Terrace Sequence of the Lower Rhine Basin corresponds with the Younger Main Terrace (Jüngere Hauptterrasse: Quiring, 1926) in the Middle Rhine valley. 
5. The Middle Terrace Sequence and the Low Terraces:

During this time the Rhine formed a terrace staircase along the river course in both, the Lower and the Middle Rhine area. The most completed terrace staircase is developed near Grevenbroich in the Lower Rhine Basin (Brunnacker et al., 1978). The Middle Terrace complex can be subdivided into four units, from the oldest MT1 to the youngest MT4. The Low Terrace is also subdivided in an older and a younger LT. The accumulation body of these terraces consist of coarse gravel from river Rhine with 35 to $22 \%$ of quartz pebbles in the Middle Terraces and around $20 \%$ in the Low Terrace (Burghardt \& Brunnacker, 1974). The heavy mineral assemblage is characterized by the dominance of volcanic minerals. As a lithological unit these sediments are called Urk Formation (Zonneveld, 1958, Heide \& Zagwijn, 1967) in the Netherlands.

\section{Interpretation}

As there are many exposures in the Lower Rhine Basin, owing to the large brown coal open cast mines and some smaller gravel pits, the drainage pattern in this area, based on petrographical analyses, can be re- constructed (Figs. 4 and 5).

During the Late Tertiary two large river systems supplied the Lower Rhine Basin with sand and gravel, the Rhine from SE and the Eastern Meuse from SW, forming the Kieseloolite Formation. The Rhine was the dominating river. Gravel and sand from this river were accumulated and are exposed on the Ville, in the Erft Basin, and in the Venlo Graben. The Meuse sediments are restricted to the SW, south of Geilenkirchen. North and NE of Geilenkirchen, accumulation of Rhine/Maas mixed sediment took place. A remarkable change in the petrographic composition of sediments occurred within the youngest member of the Pliocene beds - the Reuver Clay (Fig. 4). Garnet, epidote and green hornblende became dominant, replacing the extremely stable minerals of the Kieseloolite Formation. Abundant mica and feldspar grains as well as the carbonate content of the sediments are also characteristic for the lithofacies of this time.

This new lithofacies is exposed in the Ville area, in the Hambach open cast mine in the centre of the Erft Basin, in the Inden open cast mine in the Rur Graben (= Roer Valley Graben), and in the Brüggen-Reuver area (Fig.4). The entire Lower Rhine Basin was more or less influenced by the Rhine river system accumulating the described lithofacies. Yet, the sedimentological features did not change. The petrographic transi-

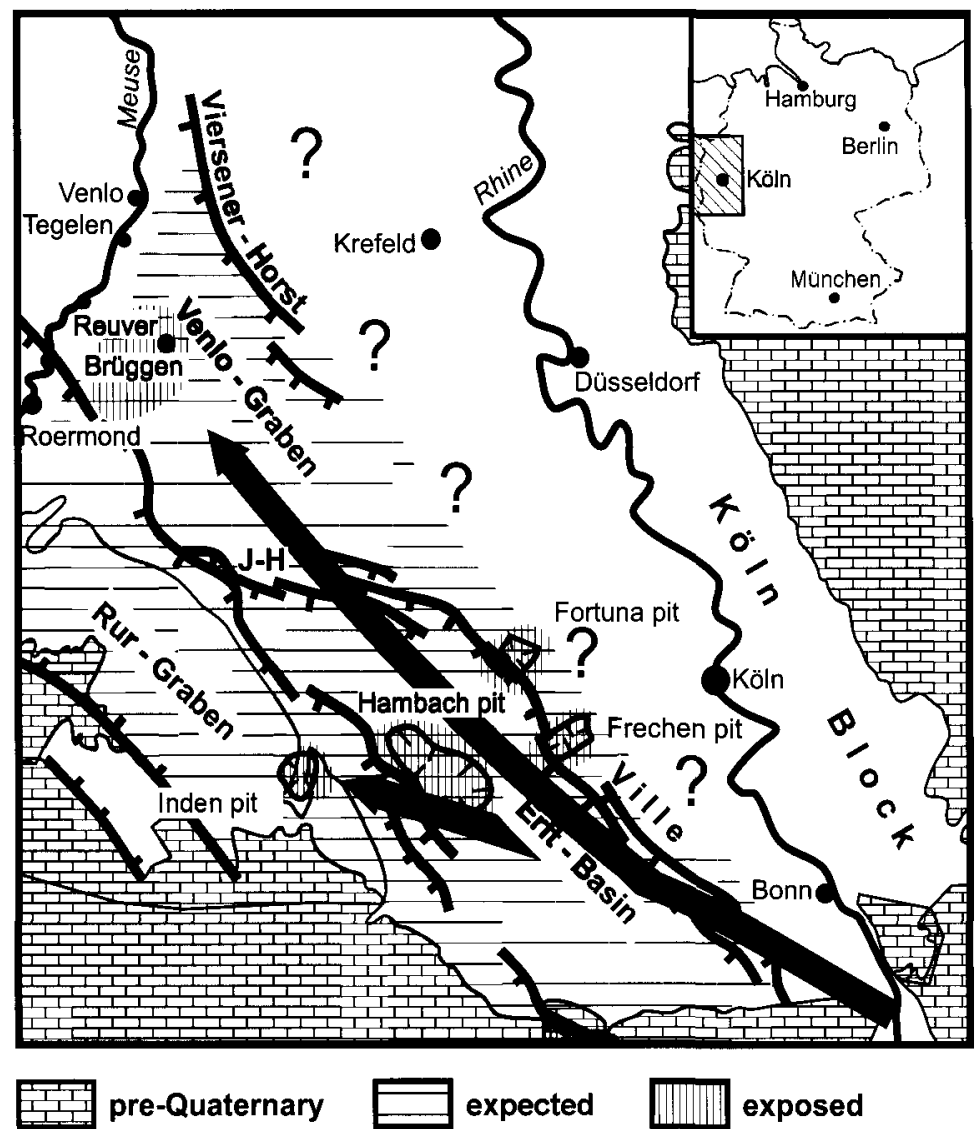

Fig. 4. Lower Rhine basin drainage pattern during the upper part of the Reuverium. Rhine sediments with a garnet-epidote-green hornblende association are found all over the area. 

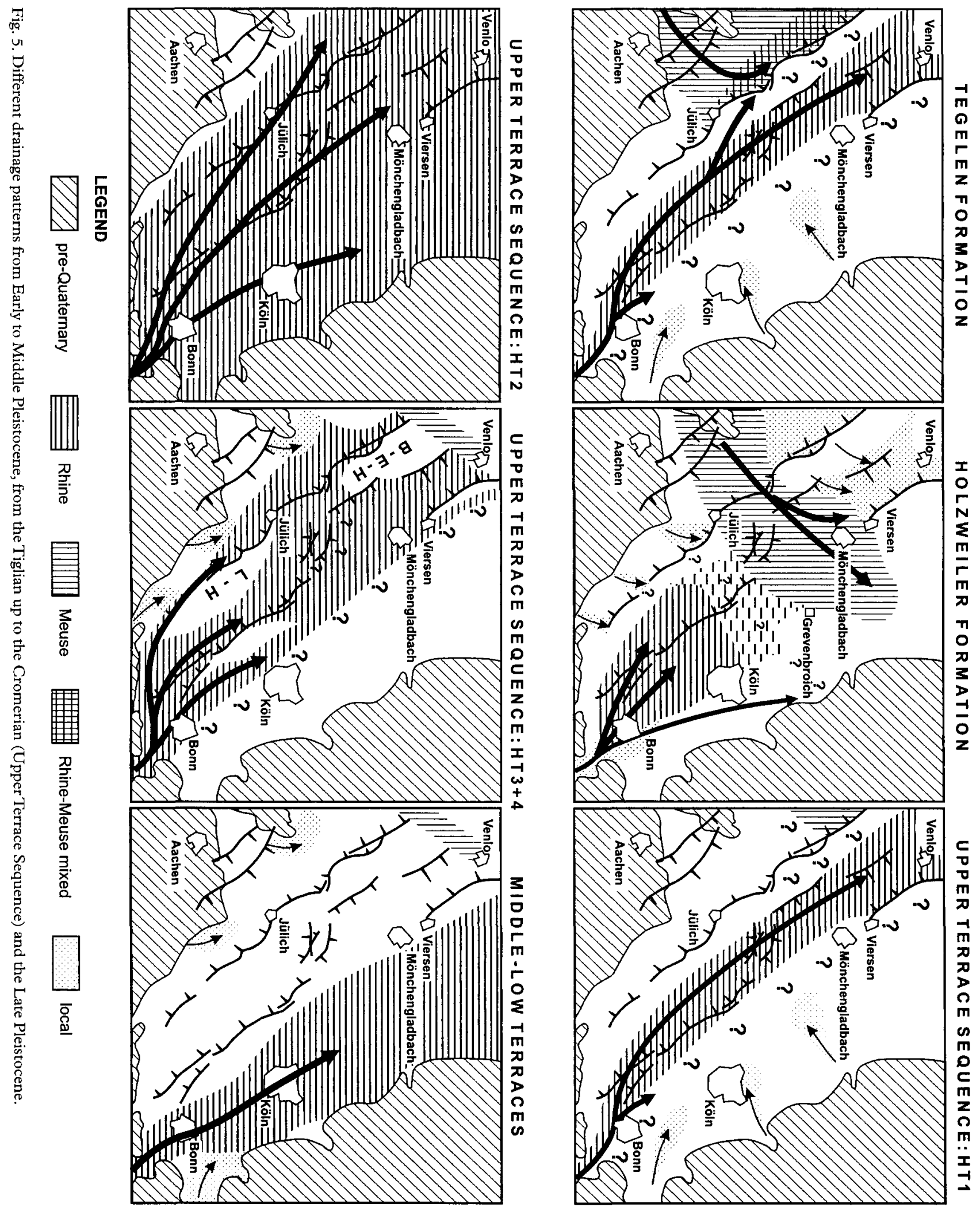

tion took place in the Reuver clay, a clay horizon with peat layers. This obvious change in the petrographic sediment composition is correlated with the drainage area now open to the Alps, evidencing the first influx of alpine material into the Lower Rhine Basin. The extension of the drainage system might be connected with a tectonic event in the southern part of the Upper Rhine Graben. Due to the carbonate content of this new lithofacies, remains of gastropods and mammals are preserved. The Reuver clay is an excellent marker horizon to characterise the Pliocene/Pleistocene boundary, based on gastropod and mammal 
faunas, pollen-analysis and palaeomagnetic measurements.

The petrographic composition of the following Pleistocene Tegelen Formation (Fig. 5) is similar to the uppermost Reuver clay. However, the sediments can only be found in subsiding parts of the Erft Basin and the Venlo Graben. In the Rur Graben there are some relicts of a mixture of Rhine and Meuse sediments (Prüfert 1998) in the areas with the highest rate of subsidence. These sediments of the Tegelen Formation are not exposed in the uplifted parts - the Köln-Block and the Brüggen-Erkelenz-Horst and its continuation to SE, along the Rur-Fault-System. It is obscure, whether this is due to deposition or to later erosion.

However, pure Rhine sediments from that time are exposed in the Venlo Graben near Venlo and Tegelen, pointing to a Rhine running from SE to NW through the whole basin. This is remarkable, because in the Holzweiler Formation (Fig. 5) a completely different drainage pattern developed. The lower part of the Holzweiler Formation in the central part of the Lower Rhine Basin consists of coarse gravel from the Meuse. They were deposited by a river running from the SW to NE, perpendicular to the Rur-Graben and the Jackerather Horst, towards the recent Rhine valley north of Grevenbroich. This SW-NE running Meuse River completely cut off of the Venlo Graben and the NW part of the Lower Rhine Basin from the Rhine drainage system. It can be assumed that river Rhine drained the east of the basin only, just as it does today.

In the middle part of the Holzweiler Formation there is almost the same drainage pattern, but in general the sediments are finer grained and sandy, intercalated by some humic clay beds. The upper part of the Holzweiler Formation consists of coarse gravel reaching as far to the NE as sediments of that period have been preserved, up to Grevenbroich. Farther $\mathrm{NE}$, information is lacking due to younger erosion by the Rhine.

With the next lithological unit, the Upper Terrace Sequence (Fig. 5), formerly called Younger Main Terrace, the drainage pattern again changed in $\mathrm{SW}-\mathrm{NE}$ direction. These sediments are assumed to have their continuation in the Sterksel Formation in the Netherlands. The section is subdivided into four subunits HT1 - HT4.

HT1 sediments are found only in areas with strong subsidence in the Erft Basin and the Venlo Graben (Fig. 5).

In the Rur Graben equivalents of HT1 are probably missing, or they are represented by gravely sand carried by the river Meuse, or there is a mixture of sediments from the Rhine and Meuse rivers (Prüfert, 1998).

During the period of HT2 (Fig. 5), the Rhine once again drained the whole Lower Rhine Basin. Sediments of the HT2 are exposed in the complete Lower Rhine Basin. Gravel and sand of this unit unconformably covered sediments of different age and different provenance.

It has to be considered that there was intensive erosion in the basin itself and at the borders in the East and at the slopes of the Eifel in the SW. This erosion period was followed by an accumulation spread over the Lower Rhine Basin. It is hard to believe that this should have taken place within the short period of Glacial B of the Cromerian Complex. Most probably, there is much more time hidden in this unit, i.e. more information is needed.

Since the formation of HT3, different blocks of the basin started to subside locally (Fig. 5). Lommersum Horst and Brüggen-Erkelenz-Horst are not covered with this unit. On some parts of the Ville HAT3 sediments are lacking and there is not any exposure of HT3 sediments on the Viersen-Horst. East of Ville and Viersen Horst no HT3 sediments are found. But there is evidence that the Rhine drained also in the eastern part of the basin, because otherwise the river would not have been able to flow into this area during increasing uplift of the Köln-Block.

The beginning of the uplift in the southern Lower Rhine Basin at the end of the formation of the Upper Terrace Sequence (HT4) is coupled with an incision of river Rhine forming the terrace steps of the Middle and Low Terraces. Since that time, the river Rhine was trapped and has been draining the eastern part of the Lower Rhine Basin only. The accumulation of the Younger Middle Terrace and the Low Terrace are worth mentioning. These sediments are characterized by abundant material from the Quaternary Eifel volcanic field.

\section{References}

Boenigk, W., 1978a. Die flußgeschichtliche Entwicklung der Niederrheinischen Bucht im Jungtertiär und Altquartär. Eiszeitalter und Gegenwart 28: 1 - 9.

Boenigk, W., 1978b. Gliederung der altquartären Ablagerungen in der Niederrheinischen Bucht.-Fortschritte Geologie Rheinland Westfalen 28: $135-212$.

Breddin, H., 1955. Die Gliederung der altdiluvialen Hauptterrasse von Rhein und Maas in der Niederrheinischen Bucht. Der Niederrhein 3/4 1955:1 - 4 .

Brunnacker, K., 1980. Exkursion I. Mittel- und Niederrhein. Tagung der Deutschen Quartärvereinigung 1980, Aachen: 110 pp.

Brunnacker, K., Boenigk, W., Dolezalek, B., Kempf, E.K., Koči, A., Mentzen, H., Razi Rad, M. \& Winter, K.-P., 1978. Die Mittelterrassen am Niederrhein zwischen Köln und Mönchengladbach. 
Fortschritte der Geologie in Rheinland und Westfalen 28: 277 324.

Burghardt, E. \& Brunnacker, K., 1974. Quarzzahl und -rundung in Schottern der Niederrheinischen Bucht. Decheniana 126: 333352.

Doppert, J.W.Chr., Ruegg, G.H.J., Van Staalduinen, C.J., Zagwijn, W.H. \& Zandstra, J.G., 1975. Formaties van het Kwartair en boven-Tertiair in Nederland. In: Zagwijn, W.H. \& Van Staalduinen, C.J. (eds): Toelichting bij Geologische overzichtskaarten van Nederland: 11-56.

Ebbing, J.H.J., Weerts, H.J.T., Westerhoff, W.E., Cleveringa, P. \& De Lang, F.D., 1999. De lithostratigrafische indeling van Nederland. Formaties uit het Tertiair en Kwartair. Nederlands Instituut voor Toegepaste Geowetenschappen TNO, Internal report: Rapport 99-141-B: 38 pp.

Fliegel, G. \& Stoller, J., 1913. Jungtertiäre und altdiluviale pflanzenführende Ablagerungen im Niederrheingebiet. Jahrbuch Königlich preußische geologische Landes-Anstalt (für das Jahr 1910), 31: 227-257.

Hoselmann, Chr., 1994. Stratigraphie des Hauptterrassenbereichs am unteren Mittelrhein. Geologisches Institut der Universität zu Köln, Sonderveröffentlichungen 96: 235 pp.

Kaiser, K.H.,1961. Gliederung und Formenschatz des Pliozäns und Quartärs am Mittel- und Niederrhein sowie in den angrenzenden Niederlanden unter besonderer Berücksichtigung der Rheinterrassen. In: Köln und die Rheinlande. Festschrift zum 33. Deutschen Geographentag 1961 in Köln. Steiner: 236-278.

Klostermann, J., 1992. Das Quartär der Niederrheinischen Bucht. (Geologisches Landesamt Nordrhein-Westfalen) Krefeld: $200 \mathrm{pp}$. Prüfert, A., 1994. Erläuterungen zu Blatt 5002 Geilenkirchen.
Geologische Karte von Nordrhein-Westfalen: 165 pp.

Prüfert, A., 1998. Erläuterungen zu Blatt 4902 Heinsberg. Geologische Karte von Nordrhein-Westfalen: 178 pp.

Quiring, H., 1926. Die Schrägstellung der Westdeutschen Großscholle im Versuch einer Terrassenchronologie des Rheins. Jahrbuch königlich preußische geologische Landes-Anstalt 47: 486-558.

Schnütgen, A., 1974. Die Hauptterrassenfolge am linken Niederrhein aufgrund der Schotterpetrographie. Forschungsberichte des Landes Nordrhein-Westfalen, Nr.2399: 149 pp.

Van der Heide, S. \& Zagwijn, W.H., 1967. Stratigraphical nomenclature of the Quaternary deposits in the Netherlands. Mededelingen van de Geologische Stichting, N.S. 18: 23-29.

Weerts, H.J.T., Cleveringa, P., Ebbing, J.H.J., de Lang, F.D. \& Westerhoff, W.E., 2000. De lithostratigrafische indeling van Nederland - Formaties uit het Tertiair en Kwartair. Nederlands Instituut voor Toegepaste Geowetenschappen TNO, Internal report: Rapport 00-95-A: 38 pp.

Zagwijn, W.H., 1957. Vegetation, climate and time correlations in the Early Pleistocene of Europe. Geologie en Mijnbouw, N.S. 19: 233-244.

Zagwijn, W.H., 1960. Aspects of the Pliocene and Early Pleistocene vegetation in the Netherlands. Mededelingen van de Geologische Stichting, Serie C-III-1-No. 6: 78 pp.

Zonneveld, J.I.S., 1947. Het Kwartair van het Peelgebied en de naaste omgeving (een sedimentpetrologische studie). Mededelingen van de Geologische Stichting, serie C-VI-No 3: $223 \mathrm{pp}$.

Zonneveld, J.I.S., 1958. Litho-stratigrafische eenheden in het Nederlandse Pleistoceen. Mededelingen van de Geologische Stichting, N.S. 12: 31-64. 